\title{
Overexpression of the Interferon-Inducible Isoform 4 of NCOA7 Dissects the Entry Route of Enveloped Viruses and Demonstrates that HIV Enters Cells via Fusion at the Plasma Membrane
}

\author{
Nikolas Herold ${ }^{1,2}$ (1) \\ 1 Childhood Cancer Research Unit, Department of Women's and Children's Health, Karolinska Institutet, \\ 17176 Stockholm, Sweden; nikolas.herold@ki.se \\ 2 Paediatric Oncology, Theme Women's and Children's Health, Karolinska University Hospital, \\ 17176 Stockholm, Sweden
}

Received: 20 January 2019; Accepted: 27 January 2019; Published: 29 January 2019

\begin{abstract}
The HIV-1 entry-route is a matter of ongoing controversy, and there is evidence for fusion either at the cell surface or from within endosomes. A recent report demonstrated that isoform 4 of nuclear receptor coactivator 7 ( $\left.\mathrm{NCOA}_{\text {iso }}\right)$ interacts with endolysosomal vacuolar-type $\mathrm{H}^{+}$-ATPase (V-ATPase), increasing lytic activity and thereby severely affecting the entry of vesicular stomatitis virus glycoprotein (VSV-G)-mediated, but not HIV-Env-mediated, entry and infection. As basal expression of $\mathrm{NCOA}_{\text {iso4 }}$ is low in the absence of type- 1 interferons, its overexpression is a novel tool to study viral entry.
\end{abstract}

Keywords: human immunodeficiency virus; entry; endocytosis; fusion; NCOA7; VSV-G; Env; plasma membrane

Enveloped viruses need to fuse with a cellular membrane to deliver their viral content to the cytosol of their host cell. Following receptor engagement, fusion can occur directly at the plasma membrane or subsequent to endocytosis. For retroviruses, both modes of entry exist: ecotropic murine leukaemia virus and avian leukosis virus are paradigmatic examples for fusion at the plasma membrane and from within endosomes, respectively [1,2]. Cellular uptake of HIV-1 particles into endomembrane compartments has been identified previously [3-5], but has traditionally been considered a non-productive and/or recycling pathway [3,6]. Several lines of evidence have been reported for the plasma membrane being the primary site of HIV-1 entry: (i) the endocytic signal peptide in CD4 is dispensable for HIV-1 infection [7]; (ii) expression of HIV-Env efficiently mediates cell-to-cell fusion [8]; and (iii) HIV-1 infection is not dependent on a low-pH cue [4,9]. Nevertheless, direct visualisation of HIV-1 fusion at endomembranes has been reported [10]. Furthermore, at least in non-physiological adherent model cell lines, inhibitors of acidification led to enhanced HIV-1 infection, suggesting that HIV-1 fusion at endomembranes is increased if lysosomal degradation is prevented [11,12]. In induced pluripotent stem cell-derived macrophages that are endocytically more active as compared to T-cells, the forced increase of fusion at the plasma membrane by overexpression of Lck (reducing CD4 endocytosis) led to increased reverse transcription, but did not lead to increased productive infection [13]. In addition, the inhibition of dynamin-dependent endocytosis by the overexpression of a dominant-negative mutant as well as small molecule inhibitors of clathrin-mediated endocytosis reduced HIV-1 infectivity in adherent reporter cell lines [14,15], even though these approaches did not affect fusion and infection efficiency in T-cells [16]. However, dynamin-2 has been reported to contribute to fusion at the plasma membrane in T-cells by stabilising the fusion pore $[17,18]$. A similar role for dynamin-2 has been suggested for the cell-to-cell transmission of HIV-1; 
nevertheless, the site of fusion following cell-to-cell transmission of HIV-1 is as controversial as cell-free virus entry $[19,20]$.

More recently, work by Miyauchi and co-workers suggested that HIV-1 enters T-cells exclusively via endocytosis $[21,22]$. These results are based on single-virus tracking that uses viral particles carrying separate labels in their lipid membrane and their viral core. Hence, live-cell imaging and the monitoring of the site, sequence and type of colour separation allowed the direct visualisation and quantification of putative fusion events. In conflict with these data, exploiting the fact that HIV-Env-mediated fusion is arrested at temperatures below $23{ }^{\circ} \mathrm{C}$, while endocytosis still occurs, we showed by time-of-addition experiments with the membrane-impermeable fusion inhibitor T-20 that HIV-1 fusion and infection are not dependent on endocytosis in T-cells [16]. This was true for both primary-patient isolated and lab-adapted HIV-1 glycoproteins, irrespective of their co-receptor tropism [16]. The discrepancies between our work and the work by Miyauchi et al. have been discussed, but could not be completely resolved [23,24].

The family of interferon-induced transmembrane proteins (IFITMs) restrict virus-cell fusion, but cannot faithfully tell the mode of entry apart, as they inhibit fusion both at the plasma membrane and from within endosomes [25]. Nevertheless, one report inferred from the differential susceptibility of CXCR4- and CCR5-tropic HIV-1 envelope glycoproteins to distinct IFITM homologues that co-receptor tropism might define the subcellular site of fusion; IFITM-2 and 3, located at endosomes and lysosomes, restricted X4-Env, whilst IFITM-1, predominantly found at the plasma membrane, restricted R5-Env bearing HIV-1 [19,26].

In the December issue of Nature Microbiology, Doyle et al. demonstrate that another interferon-inducible factor, isoform 4 of nuclear receptor coactivator 7 ( $\left.\mathrm{NCOA}_{\text {iso }}\right)$, inhibits fusion and infection triggered by viral glycoproteins known to mediate entry at endomembranes, but not of glycoproteins that fuse at the plasma membrane [27]. Mechanistically, this is mediated by direct $\mathrm{NCOA}_{\text {iso4 }}-\mathrm{V}$-ATPase interaction at endosomes, leading to increased acidic proteolysis of the endosomal cargo. Given that basal NCOA $7_{\text {iso4 }}$ expression is low in the absence of interferon, a major implication of this study is that sensitivity to overexpression of $\mathrm{NCOA}_{\text {iso4 }}$ can dissect whether an enveloped virus enters cells via fusion at the plasma membrane or from within endosomes, and will certainly become a standard assay for studies into early viral life-cycles. Accordingly, VSV-G-pseudotyping sensitises HIV-1 to $\mathrm{NCOA}_{\text {iso4 }}$ restriction, whereas wild-type HIV-1 is resistant to $\mathrm{NCOA}_{\text {iso4 }}$.

Effectively, this study shows that the entry of HIV-1 does not require endocytosis and thus occurs bona fide at the plasma membrane, at least under experimental conditions using the glioma cell line U87MG CD4 ${ }^{+} \mathrm{CXCR}^{+}$and X4-tropic lab-adapted NL4-3-Env. Future work will have to address whether the overexpression of $\mathrm{NCOA}_{\text {iso4 }}$ also ablates HIV-1 infection in primary target cells of HIV-1, namely T-cells and macrophages. Furthermore, since co-receptor usage has been implicated in the viral entry route [26] and lab adaptation might alter entry requirements, primary Env isolates should be subjected to this novel assay. This promises to contribute importantly to, or even resolve, the controversy of the HIV-1 entry route.

Acknowledgments: The author would like to thank Torsten Schaller for critical discussion and the Swedish Childhood Cancer Foundation for funding (PR2018-0016).

Conflicts of Interest: The author declares no conflict of interest.

\section{References}

1. Portis, J.L.; McAtee, F.J.; Evans, L.H. Infectious entry of murine retroviruses into mouse cells: Evidence of a postadsorption step inhibited by acidic pH. J. Virol. 1985, 55, 806-812. [PubMed]

2. Mothes, W.; Boerger, A.L.; Narayan, S.; Cunningham, J.M.; Young, J.A. Retroviral entry mediated by receptor priming and low $\mathrm{pH}$ triggering of an envelope glycoprotein. Cell 2000, 103, 679-689. [CrossRef]

3. Marechal, V.; Clavel, F.; Heard, J.M.; Schwartz, O. Cytosolic Gag p24 as an index of productive entry of human immunodeficiency virus type 1. J. Virol 1998, 72, 2208-2212. 
4. Stein, B.S.; Gowda, S.D.; Lifson, J.D.; Penhallow, R.C.; Bensch, K.G.; Engleman, E.G. pH-independent HIV entry into CD4-positive T cells via virus envelope fusion to the plasma membrane. Cell 1987, 49, 659-668. [CrossRef]

5. Pudney, J.; Song, M.J. Electron microscopic analysis of HIV-host cell interactions. Tissue Cell 1994, 26, 539-550. [CrossRef]

6. Schaeffer, E.; Soros, V.B.; Greene, W.C. Compensatory link between fusion and endocytosis of human immunodeficiency virus type 1 in human CD4 T lymphocytes. J. Virol. 2004, 78, 1375-1383. [CrossRef]

7. Pelchen-Matthews, A.; Clapham, P.; Marsh, M. Role of CD4 endocytosis in human immunodeficiency virus infection. J. Virol. 1995, 69, 8164-8168.

8. Lifson, J.D.; Reyes, G.R.; McGrath, M.S.; Stein, B.S.; Engleman, E.G. AIDS retrovirus induced cytopathology: giant cell formation and involvement of CD4 antigen. Science 1986, 232, 1123-1127. [CrossRef]

9. McClure, M.O.; Marsh, M.; Weiss, R.A. Human immunodeficiency virus infection of CD4-bearing cells occurs by a pH-independent mechanism. Embo J. 1988, 7, 513-518. [CrossRef]

10. Goto, T.; Harada, S.; Yamamoto, N.; Nakai, M. Entry of human immunodeficiency virus (HIV) into MT-2, human T cell leukemia virus carrier cell line. Arch. Virol. 1988, 102, 29-38. [CrossRef]

11. Fredericksen, B.L.; Wei, B.L.; Yao, J.; Luo, T.; Garcia, J.V. Inhibition of endosomal/lysosomal degradation increases the infectivity of human immunodeficiency virus. J. Virol. 2002, 76, 11440-11446. [CrossRef] [PubMed]

12. Wei, B.L.; Denton, P.W.; O’Neill, E.; Luo, T.; Foster, J.L.; Garcia, J.V. Inhibition of lysosome and proteasome function enhances human immunodeficiency virus type 1 infection. J. Virol. 2005, 79, 5705-5712. [CrossRef]

13. van Wilgenburg, B.; Moore, M.D.; James, W.S.; Cowley, S.A. The productive entry pathway of HIV-1 in macrophages is dependent on endocytosis through lipid rafts containing CD4. PLoS ONE 2014, 9, e86071. [CrossRef] [PubMed]

14. Daecke, J.; Fackler, O.T.; Dittmar, M.T.; Krausslich, H.G. Involvement of clathrin-mediated endocytosis in human immunodeficiency virus type 1 entry. J. Virol. 2005, 79, 1581-1594. [CrossRef] [PubMed]

15. von Kleist, L.; Stahlschmidt, W.; Bulut, H.; Gromova, K.; Puchkov, D.; Robertson, M.J.; MacGregor, K.A.; Tomilin, N.; Pechstein, A.; Chau, N.; et al. Role of the clathrin terminal domain in regulating coated pit dynamics revealed by small molecule inhibition. Cell 2011, 146, 471-484. [CrossRef] [PubMed]

16. Herold, N.; Anders-Osswein, M.; Glass, B.; Eckhardt, M.; Muller, B.; Krausslich, H.G. HIV-1 entry in SupT1-R5, CEM-ss, and primary CD4+ T cells occurs at the plasma membrane and does not require endocytosis. J. Virol. 2014, 88, 13956-13970. [CrossRef]

17. Jones, D.M.; Alvarez, L.A.; Nolan, R.; Ferriz, M.; Sainz Urruela, R.; Massana-Munoz, X.; Novak-Kotzer, H.; Dustin, M.L.; Padilla-Parra, S. Dynamin-2 Stabilizes the HIV-1 Fusion Pore with a Low Oligomeric State. Cell Rep. 2017, 18, 443-453. [CrossRef]

18. Aggarwal, A.; Hitchen, T.L.; Ootes, L.; McAllery, S.; Wong, A.; Nguyen, K.; McCluskey, A.; Robinson, P.J.; Turville, S.G. HIV infection is influenced by dynamin at 3 independent points in the viral life cycle. Traffic 2017, 18, 392-410. [CrossRef]

19. Jakobsdottir, G.M.; Iliopoulou, M.; Nolan, R.; Alvarez, L.; Compton, A.A.; Padilla-Parra, S. On the Whereabouts of HIV-1 Cellular Entry and Its Fusion Ports. Trends Mol. Med. 2017, 23, 932-944. [CrossRef]

20. Sloan, R.D.; Kuhl, B.D.; Mesplede, T.; Munch, J.; Donahue, D.A.; Wainberg, M.A. Productive entry of HIV-1 during cell-to-cell transmission via dynamin-dependent endocytosis. J. Virol. 2013, 87, 8110-8123. [CrossRef]

21. Miyauchi, K.; Kim, Y.; Latinovic, O.; Morozov, V.; Melikyan, G.B. HIV enters cells via endocytosis and dynamin-dependent fusion with endosomes. Cell 2009, 137, 433-444. [CrossRef] [PubMed]

22. de la Vega, M.; Marin, M.; Kondo, N.; Miyauchi, K.; Kim, Y.; Epand, R.F.; Epand, R.M.; Melikyan, G.B. Inhibition of HIV-1 endocytosis allows lipid mixing at the plasma membrane, but not complete fusion. Retrovirology 2011, 8, 99. [CrossRef]

23. Marin, M.; Melikyan, G.B. Can HIV-1 entry sites be deduced by comparing bulk endocytosis to functional readouts for viral fusion? J. Virol. 2015, 89, 2985. [CrossRef] [PubMed]

24. Herold, N.; Muller, B.; Krausslich, H.G. Reply to "Can HIV-1 entry sites be deduced by comparing bulk endocytosis to functional readouts for viral fusion?". J. Virol. 2015, 89, 2986-2987. [CrossRef] [PubMed]

25. Smith, S.; Weston, S.; Kellam, P.; Marsh, M. IFITM proteins-cellular inhibitors of viral entry. Curr. Opin. Virol. 2014, 4, 71-77. [CrossRef] 
26. Foster, T.L.; Wilson, H.; Iyer, S.S.; Coss, K.; Doores, K.; Smith, S.; Kellam, P.; Finzi, A.; Borrow, P.; Hahn, B.H.; et al. Resistance of Transmitted Founder HIV-1 to IFITM-Mediated Restriction. Cell Host Microbe 2016, 20, 429-442. [CrossRef] [PubMed]

27. Doyle, T.; Moncorgé, O.; Bonaventure, B.; Pollpeter, D.; Lussignol, M.; Tauziet, M.; Apolonia, L.; Catanese, M.-T.; Goujon, C.; Malim, M.H. The interferon-inducible isoform of NCOA7 inhibits endosome-mediated viral entry. Nat. Microbiol. 2018, 3, 1369-1376. [CrossRef]

(C) 2019 by the author. Licensee MDPI, Basel, Switzerland. This article is an open access article distributed under the terms and conditions of the Creative Commons Attribution (CC BY) license (http://creativecommons.org/licenses/by/4.0/). 